\title{
Analysis of costs of accidents involving motorcyclists in Jataí - Goiás in the period from 2013 to 2015
}

Juliana Freitas Silva ( $\sim$ jujufresi09@gmail.com )

Universidade Federal de Jatai https://orcid.org/0000-0002-5709-5704

Maria José Rodrigues

Universidade Federal de Jatai

Research

Keywords: Traffic accidents, costs, victims

Posted Date: February 19th, 2021

DOI: https://doi.org/10.21203/rs.3.rs-210289/v1

License: (c) (1) This work is licensed under a Creative Commons Attribution 4.0 International License.

Read Full License 


\section{Abstract \\ Background}

The occurrence of traffic accidents is a public health problem present throughout Brazil. These accidents generate consequences of personal, social and economic nature. Thus, our objective is to analyze the costs of accidents involving motorcyclists, according to the type of accident, with or without victim, using data taken from traffic accident reports provided by the Military Police in the years 2013 to 2015.

\section{Methods}

The data extracted from these reports were analyzed based on the reports of the Institute of Applied Economic Research and the Informatics Department of the Unified Health System. To arrive at the corrected calculation, the accumulated Consumer Price Index for each year was also used.

\section{Results}

In Jataí, 1,118 traffic accidents were recorded, 256 without victims and 862 with victims in the analyzed period. Such accidents cost the municipality more than fifteen million reais from 2013 to 2015, costs that involve production losses for society, medical-hospital costs, early retirements, and police and judicial costs. This database was also used to generate a map showing the density of accidents for the same period, which made it possible to identify the neighborhoods with the highest traffic occurrences in the city of Jataí.

\section{Conclusions}

These data are tools that enable a deep reflection on the subject, besides serving as a parameter for establishing road safety policies, mapping the occurrences, as well as improving factors that minimize traffic accidents. Analysis of these data makes it possible to understand the expenses and describe the places where traffic accidents occurred in the city of Jataí, GO, Brazil.

\section{Background}

According to the World Health Organization (WHO, 2008), traffic accidents are defined as "every accident with vehicle occurred on public road, which is defined as the total width between two limits of property of every land or path open to the public, either by law or by custom, for the movement of people or goods from one place to another" (BRASIL, 2016, p.01).

In Brazil, the number of traffic accidents in 2009 was 19 per 100,000 inhabitants, increasing to 23.4 per 100,000 inhabitants in 2014 . These figures placed the country among the 10 with the highest number of 
deaths, being the highest in South America for this indicator (WHO, 2015).

According to data from the Informatics Department of the Unified Health System (DATASUS) and the Interagency Health Information Network (RIPSA), in 2016, accidents and violence are among the prominent external causes for the country's morbimortality pattern since the 1980s, and traffic accidents represent the second leading cause of death among external causes (DATASUS/RIPSA, 2016). When compared with reports such as that of WHO (2014), these figures show the same pattern seen in low- and middle-income countries in America, where homicides lead this group.

According to Simões (2001), traffic accidents in our country have reached high levels, with a large number of injured victims and property damage. This occurs, among other reasons, due to the progressive increase in the occupation of urban roads because of the increase in the number of trips made by cars and motorcycles.

Very common and popular motorcycles gain more space as the population needs to travel to more peripheral areas to live, consequently being further away from their workplaces and public goods and services. Other factors that favor the increased number of motorcycles on the streets are home delivery services and the traffic of motorcycle taxi drivers to meet the demand of the current world, which requires everything within reach quickly and effectively.

This category of vehicle is considered vulnerable because the physical structure does not protect the driver's body. In an attempt to mitigate the risks, the Brazilian Traffic Code (CTB), in item I of Articles 54 and 55 and in items I and II of Article 244, present the rules of conduct for motorcycle users and passengers and details the rules for the use of helmets, besides presenting the penalties for non-use or incorrect use. Despite that, disrespect to traffic signs and other norms present in the CTB is often observed on the streets.

The Institute of Applied Economic Research released studies in 2003 and 2006 which show that $75 \%$ of vehicle owners in the country have no interest in paying any increment in the motor vehicle property tax (IPVA) to increase investments aimed at reducing traffic accidents. Thus, it demonstrates the lack of interest in road safety, on the part of both public authorities and users.

In this context, this article is part of a more comprehensive study on the spatialization of traffic accidents in the city of Jataí - GO. Our goal here is to analyze the costs of these accidents involving motorcyclists, according to the type of accident, with or without victim, using data obtained from traffic accident reports (TAR) provided by the Military Police (MP) in the years 2013 to 2015.

\section{Study area and importance of geography in public health studies}

The study area is located in the city of Jataí, a municipality in the state of Goiás, Brazil, which has a population of 102,065 inhabitants according to estimates by the Brazilian Institute of Geography and 
Statistics (IBGE) of 2020. According to the last census of 2010, Jataí had a population of 88,006 people, of which 81,010 were in the urban area and 6,996 in the rural area, distributed in a territorial area of $7,174,220 \mathrm{~km}^{2}$, whose population density was 12.27 inhabitants $/ \mathrm{km}^{2}$. The period considered in this study was from 2013 to 2015, and the data of accidents involving motorcyclists were collected. Figure 1 shows the location and urban perimeter of the study area with the highways (BR 158 and 364) that intercept it.

Establishing the costs of accidents makes it possible not only to reflect on cause and effect factors, but also to create cost-benefit analyses that can provide the basis for verifying the need for road safety, in addition to other points that can minimize the occurrence of future accidents.

Together with the study on costs, the spatialization of accidents provides an overview of the places of occurrence of these events. At this point, geography helps in the understanding of space and makes it possible to establish a relationship between the subject and the surrounding environment. For the concept of space, it is understood that the space of traffic is social and, therefore, is one that "is appropriated, transformed and produced by society" (SOUZA, 2013).

There are several ways to help us know the space in which we live. According to Santos and Barcellos (2006), "maps are extremely useful instruments that help us in this task, because they allow us to represent some concrete aspects of the geographical space". However, for this to be performed properly, technical instruments are needed for this understanding of space.

Geotechnologies are the set of technologies for collecting, processing, analyzing and providing information with geographical reference, according to Rosa (2005). Geographic Information Systems (GIS) and the products of geoprocessing and remote sensing (satellite images, aerial photographs) are part of this set of geotechnologies.

Souza and Costa (2016) state that geoprocessing has been an indispensable tool to analyze the transformations resulting from the process of urban occupation, and geotechnologies can be used for: decision-making in the urban environment, through traffic planning and control; expansion of the road system, planning and supervision of public transport; as well as vertical and horizontal signaling and critical points.

The use of GIS in the health field comes to assist in studies on the population's need and to relate it to the socioeconomic situation of those involved. In this context, Guimarães $(2015$, p. 34) points out that "spatial statistics studies based on GIS, associated with qualitative research in the area, constitute the most recent development of geographic studies on health".

In this premise, there are several medical conditions and diseases that affect our society and that must be analyzed using a geographical approach. In this work, we will address non-communicable medical conditions related to traffic accidents. These medical conditions are now a cause of great concern among city residents, as they are responsible for a considerable number of deaths every year, especially in vulnerable categories, such as motorcyclists, pedestrians or cyclists. Considering these aspects, the first 
step towards interventional measures aimed at reducing these cases is the identification and location of these accidents.

\section{Methods}

The study is structured in a quali-quantitative research, whose variables will be number of occurrences of accidents involving motorcyclists for each year, number of accidents with victims and without victims, and calculation of the costs of these accidents.

The relevance of studying accidents specifically involving motorcyclists is presented by Waiselfisz (2013) when he states that, in a United Nations document, close to half of the victims of traffic accidents in the world are the so-called vulnerable categories (pedestrians, cyclists and motorcyclists). This proportion is even higher in middle- and low-income countries, due to the higher density of these categories. Another relevant aspect is that, in Brazil, in 2011, 66.6\% (two thirds) of traffic victims were pedestrians, cyclists and/or motorcyclists, but national trends, according to the author, point to a markedly differential evolution in the rest of the world, which are:

- Significant reductions in pedestrian mortality;

- Slight increase in the mortality of car occupants; and

- Heavy increases in the lethality of motorcyclists.

The research involved the collection of primary data from the TARs, which were made available by the Department of the 15th Military Police Battalion of the State of Goiás. For being primary data, the project was submitted to the Research Ethics Committee of the Federal University of Goiás and was approved on May 26, 2017, under protocol $n^{\circ} 2.085 .386$ and CAAE $n^{\circ}$ 62115916.3.0000.5083.

For the year 2013, the reports for the months of January and February were not available; for the year 2015, we did not have access to the reports of April. In Jataí, as in many other Brazilian municipalities, there is no adequate location and a specific worker to archive documents properly as well as to analyze the data contained in them. This factor makes the access to documents difficult for those interested, whether victims or researchers.

The information contained in the TARs was entered in a computer to create the database and, from this point, the graphs, tables and the map containing the density of accidents occurred in intersections in the years 2013 to 2015 were generated.

The calculation of the cost estimates was based mainly on the report of IPEA (2003), called "Impactos Sociais e Econômicos dos Acidentes de Trânsito nas Aglomerações Urbanas Brasileiras" (Social and Economic Impacts of Traffic Accidents in Brazilian Urban Agglomerations). In this report, Brazilian cities have a total cost with traffic accidents around R\$ 5 billion per year. The Consumer Price Index (CPI) is used as a correction factor. 
The IPEA determines that, to estimate the costs of accidents in state highways, municipal highways and urban agglomerations, the following simplified procedures were adopted:

- Direct monetary correction of the results of the original survey by the CPI;

- Direct monetary correction of the results of previous surveys for state/municipal highways and urban agglomerations by the correction factor calculated by the relationship between the costs of accidents on federal highways recorded by the Federal Highway Police in 2014 and the costs calculated in the 2005 survey; and

- Monetary correction by an index composed of the CPI combined with the variation of deaths from land transport accidents obtained from the database of the Ministry of Health, DATASUS, between the survey periods.

To support the methodology, police and judicial costs are used as parameters, in addition to losses in the material level and medical-hospital costs. Production losses for society and early retirements are also taken into account. Another aspect that influences the costs of accidents considers the variation according to the age group of the victims. According to the National Traffic Department (DENATRAN, 2001), this is due to the fact that losses for society must be computed when, in a family, one of the members dies or becomes disabled definitively or temporarily. When taking into account such losses, it can be observed that they are far beyond the medical costs inherent to each accident, as a feeling of pain and anguish remains in each family that loses a loved one, and that cannot be measured. Focusing on age, DENATRAN also points to studies showing $59 \%$ of victims in the productive age group, aged 18 to 59 years.

The IPEA (2003) establishes a unit cost for accidents in Brazil involving the factors already mentioned. The unit value corrected by the $\mathrm{CPI}$, accumulated in that year, was multiplied by the number of accidents that occurred in the city of Jataí - GO. The accidents chosen as parameters were divided between occurrences with victims, which include fatal and injured victims, and also accidents without victims. Therefore, the calculation formula is as follows:

TUC: $(\mathrm{UV} \times \mathrm{CPI}) \times \mathrm{Na}$

Where, TUC: Total Unit Cost; UV: Unit Value; CPI: correction factor; Na: number of accidents. Calculations were performed using Microsoft Excel spreadsheets, and the source of database was the official websites of the Central Bank of Brazil, DATASUS, IPEA, RIPSA, Brazilian Institute of Geography and Statistics, in addition to Calculadora do Cidadão (Citizen's Calculator), a tool made available by the federal government for calculations involving taxes and correction factor indices.

The map was generated in ArcGis 10.1 software, using the Kernel method, licensed by the Geoinformation Laboratory of the Federal University of Goiás - Regional Unit of Jataí. The cartographic base was available on the website of the Municipality of Jataí, in 2015. 
The Kernel Method, Kernel meaning "core", is a statistical method that estimates density curves from a central value. This method is used when there is a need to observe the area affected by a given phenomenon, thus allowing a broader view of the regions in which the events occurred.

According to Souza et al. (2017, p. 753), "the Kernel function identifies a normally circular window, with a radius ranging from 0 (zero) to a previously specified bandwidth, and all sampling points that are within that window are considered in the estimate."

Using this method, we interpolated traffic accidents involving motorcyclists occurred at intersections during the analyzed period. With this interpolation, it was possible to verify the concentration areas and the pattern of accidents for the chosen time interval.

\section{Results And Discussion}

\section{Costs of traffic accidents involving motorcyclists in Jataí - GO}

In the analyzed period, there were 929 accidents in 2013, 1,051 in 2014 and 322 in 2015 in the municipality of Jataí. Of this total, there were 888 accidents in the urban perimeter in 2013, 1,011 in 2014 and 316 in 2015. The decrease in the number of accidents recorded from 2014 to 2015 is due to the change in the procedure adopted by the Military Police, which began from 2015 to dispatch a crew only to occurrences with victims or in which the parties involved did not reach a consensus. For accidents without victims, drivers must enter an online platform to report the event. However, in some cases those involved do not perform this procedure of online reporting, because they reach a consensus at the time of the event, thus favoring the underreporting of accident cases.

To identify the involvement of motorcyclists in accidents, a field was created in the database to inform whether there was a motorcycle or not, so we applied this filter to delimit our data. The creation of this field was necessary because, in field 19 of the TAR, one should inform the identification and the amount of the vehicles involved, but some statements reported that a motorcyclist was involved in the accident, and it was not described in this field. Thus, we used this filter in order to minimize the concealment of occurrences with motorcyclists.

With this, we identified 1,118 occurrences that fit the profile of the study, that is, the presence of the involvement of motorcyclists and accidents that occurred within the urban perimeter of Jataí. Of a total, 419 occurred in 2013, 486 in 2014 and 213 in 2015.

Cabral, Souza and Lima (2011) identified that this group takes even more risks in the driving of vehicles, such as high speed, inadequate maneuvers and alcohol use. From the standpoint of the activity, there are also other costs associated, such as potential social security expenses that greatly increase costs to the public coffers, with the consequence of work inactivity and the need for rehabilitation.

Regarding deaths, according to data obtained from the Informatics Department of the Unified Health System - DATASUS, Jataí had 35 deaths in 2013, 36 deaths in 2014 and 39 deaths in 2015 for category 
V01 - V99 of CID-10, which refers to the category of traffic accidents. The total number of deaths represents $9.43 \%$ of the number of accidents with victims for the year $2013,8.26 \%$ for the year 2014 and $16.32 \%$ for the year 2015. This fact should be taken into account when structuring actions aimed at reducing accidents, instead of only verifying the number of accidents recorded.

For traffic accidents to be considered the underlying cause of death, this has to occur within 30 days after the event. In this case, for people who have been injured in a period longer than this, even if they are hospitalized or have other subsequent medical conditions due to the accident, leading to death, these numbers do not enter the statistics.

Deaths have consequences at various levels, depending on the position of those who are analyzing or experiencing this result. For a family that loses its loved one, death means pain, longing and absence. If the death occurred with the provider member, this family may become in need and the basics, such as food and hygiene, may be lacking. For the municipality, there are high expenses for the public coffers, a value that could be directed to other areas and even to road safety.

In the police reports, this number is five deaths for 2013 and 2014 and four deaths for 2015. This difference can be explained, because the number of deaths described in TARs and later in the surveys refers to deaths at the site, while data from DATASUS are obtained through medical records, notifications and death certificates from the health units in which these victims were treated. Queiroz (2003) explains that most victims of accidents do not die at the site, but in the health unit.

Silva (2007) describes the presumed causes for deaths that occurred during the period of study: $27 \%$ of the occurrences in 2002, 31\% in 2003 and $11 \%$ in 2004 occurred due to speeding and, for the year 2004, the most presumed cause was disobedience at the STOP sign. These data reinforce the lack of kindness in traffic and respect for other road users.

Chagas (2011, p. 27) mentions that "Brazilian traffic department units produce information with a low degree of use and reliability, thus making it impossible to establish effective traffic safety policies". Each document of a given unit that is used to record traffic accidents has a specific purpose and the lack of standardization of these information collection instruments makes it difficult to identify the elements causing these accidents.

This and other differences found in studies addressing the theme justify the need for a unified report, as this would avoid not only underreporting, but also the presence of duplicated data in the different documents. Unification would provide more reliable data and could thus serve as the basis for more effective actions to reduce the number of accidents.

By analyzing the data presented, we realized the impact of medical care services for accidents both on public health and on the lives of victims. In line with the study of IPEA (2003), the costs of traffic accidents were determined according to severity: accidents with victims or without victims for the year 2003. 
It is important to highlight that the costs of accidents involve several aspects. One of them is pointed out by the National Observatory of Road Safety (ONSV, 2016), which shows a different study, because it relates the expenses of each State to the respective populations to obtain the per capita cost of traffic accidents, that is, each Brazilian spent R\$ 255.69 throughout the year. In Goiás, the cost indicated was R\$ 381.42. This cost means how much each citizen paid throughout the year, since the expenses with traffic accidents (hospitals, doctors, infrastructure, medicines, emergency care, among others) are paid through taxes. Consequently, this resource is no longer invested in improvements such as in health, education and basic sanitation, which could have been done by the respective governments, but were not done because of traffic accidents that could be avoided.

Therefore, to characterize the costs involved in a traffic accident, the IPEA and the National Association of Public Transport - ANTP conduct research on the economic and social costs of traffic accidents in urban agglomerations of the country. These studies make it possible to aggregate both direct and indirect costs generated by traffic accidents. In the 2003 survey, the costs reported were:

- Production Loss Cost: economic losses suffered by people, due to the temporary or permanent interruption of their production activities.

- Vehicle Damage Cost: repair or replacement of damaged vehicles.

- Medical-hospital Cost: value spent on the care and treatment of victims of traffic accidents.

- Lawsuit Cost: expenses arising from the lawsuits involved.

- Traffic Jam Cost: monetary value of the time lost by vehicle occupants retained in traffic accidents.

- Social Security Cost: pensions and benefits derived from accidents paid by Social Security.

- Victim Rescue Cost: transport of victims to the medical center.

- Vehicle Removal Cost.

- Cost of Damage to Urban Structure and to the Property of Third Parties damaged or destroyed due to traffic accidents.

- Other Costs: Cost of another Means of Transport; Costs of Damage to Traffic Signs; Cost of Police Service and Traffic Agents; Family Impact.

These costs represent all possible aspects to be considered regardless of the severity of the accident. Each situation will require, if not all, a significant number of them. In the case of motorcycle accidents, the severity factor can be much higher than that for cars. Thus, considering the costs mentioned, the study found the values shown in the second column of Table 1:

Table 1 - Brazil: cost of traffic accidents, by type of accident, 2013 to 2015. 


\begin{tabular}{|llllllll|}
\hline $\begin{array}{l}\text { Accident } \\
\text { category }\end{array}$ & $\begin{array}{l}\text { Unit Cost of } \\
\text { each Accident }\end{array}$ & \multicolumn{2}{l}{$\begin{array}{l}\text { Correction index } \\
\text { (Accumulated CPI) }\end{array}$} & \multicolumn{4}{l|}{$\begin{array}{l}\text { Average unit cost of accidents updated } \\
\text { per year }\end{array}$} \\
\hline & $\mathbf{2 0 1 3}$ & $\mathbf{2 0 1 4}$ & $\mathbf{2 0 1 5}$ & $\mathbf{2 0 1 3}$ & $\mathbf{2 0 1 4}$ & $\mathbf{2 0 1 5}$ \\
\hline $\begin{array}{l}\text { With } \\
\text { victims }\end{array}$ & $\mathrm{R} \$ 161,938.44$ & 0.92 & 0.78 & 0.96 & $171,510.33$ & $172,314.83$ & $179,222.94$ \\
\hline $\begin{array}{l}\text { Without } \\
\text { victims }\end{array}$ & R\$ 3,262.00 & 0.92 & 0.78 & 0.96 & $3,454.81$ & $3,471.02$ & $3,610.17$ \\
\hline
\end{tabular}

Source: IPEA (2003) and Calculador (2018), with adaptations.

Organization: SILVA, Juliana Freitas (2018).

With the accident costs data for the year 2003, the prices for that year were updated for 2013 to 2015, the years of the data of accidents in Jataí. The values were updated using the CPI, obtained from information on the website of the Central Bank of Brazil. This index has been calculated since 1980 and is currently considered as Brazil's official inflation index. To simplify the calculation of the correction index for the period from 2003 to 2013-2015, an average value was adopted for each year, which is the cumulative average of the accumulated index for each year.

After the calculations considering the $\mathrm{CPI}$, the updated average cost of the traffic accidents per category with victim and without victim was determined. Then, based on the number of accidents per year, the average overall cost of traffic accidents for the city of Jataí was calculated. Table 2 shows the number of accidents that occurred each year in the city of Jataí and, based on the variation of the correction index accumulated in each year in the period from 2013 to 2015, Table 3 contains the updated values of the cost of traffic accidents in Brazil for the year 2003, bringing it to the years 2013 to 2015 in Jataí.

The average value of a traffic accident for the years 2013 to 2015 and the number of accidents for those same years were used to obtain the overall values of these accidents, which are the actual values of how much the accidents cost the municipality. The total is composed of the sum of the values corresponding to all years corrected with the CPI value. The values with victim and without victim were also summed to provide the actual dimension of unit and global costs, considering a relative and an accumulated frequency of the unit value.

It is important to mention that the official databases do not have complete information due to the underreporting of the occurrences. Therefore, in situations where the data are not complete, the system of averages is adopted in the numerical case and in qualitative cases, concepts of official surveys that support and substantiate the information, because it is carried out with national surveys and with reliability required in scientific research.

The values in Table 2 were obtained with the total of 2,215 traffic accidents, considering only those that occurred on urban roads and involving motorcyclists, which is the focus of this work. 
Table 2 - Jataí (GO): number of traffic accidents involving motorcyclists, 2013 to 2015.

\begin{tabular}{|llll|}
\hline Accident Category & \multicolumn{3}{c|}{ Number of Accidents per Year } \\
\hline With victims & $\mathbf{2 0 1 3}$ & $\mathbf{2 0 1 4}$ & $\mathbf{2 0 1 5}$ \\
\hline Without victims & 300 & 364 & 198 \\
\hline Total & $\mathbf{4 1 9}$ & 122 & 15 \\
\hline
\end{tabular}

Source: TAR of MP (2017)

Organization: SILVA, Juliana Freitas (2018).

When observing the figures above, it can be noted that the number of accidents with motorcyclists is quite high, although they do not represent the majority of accidents. When the three years are compared, of the 2,215 accidents, $50.47 \%$ involved motorcyclists. However, occurrences with motorcycles always cause more severe injuries, consequently higher costs, especially in the human factor, in terms of hospitalization, medical care, health and other aspects to be considered.

Table 3 - Jataí (GO): cost of traffic accidents involving motorcyclists, 2013 to 2015.

\begin{tabular}{|lllll|}
\hline Accident Category & \multicolumn{2}{l}{ Total Average Cost of Accidents } & \multicolumn{2}{l|}{ Total } \\
\hline With victims & $\mathbf{2 0 1 3}$ & $\mathbf{2 0 1 4}$ & $\mathbf{2 0 1 5}$ & \\
\hline Without victims & $\mathrm{R} \$ 5,145,309.90$ & $\mathrm{R} \$ 6,272,259.81$ & $\mathrm{R} \$ 3,548,614.21$ & $\mathrm{R} \$ 14,966,183.92$ \\
\hline Total & $\mathrm{R} \$ 5,556,432.29$ & $\mathrm{R} \$ 6,695,724.25$ & $\mathrm{R} \$ 3,602,766.76$ & $\mathrm{R} \$ 15,854,923.30$ \\
\hline
\end{tabular}

Source: TAR of MP (2017) and IPEA (2003).

Organization: SILVA, Juliana Freitas (2018).

Based on the values shown in Table 3, it is possible observe the total amount spent with traffic accidents in Jataí. In total, R\$15,854,923.30 were spent on material losses, medical-hospital costs, production loss for society, early retirements, and police and judicial costs, which could be relocated to sectors such as education, improvements in health care for the population, investments in road infrastructure, supervision and traffic engineering, among others.

In order to establish a relationship between the annual revenue of the city of Jataí, we found the annual revenue of the Municipal Health Fund for each of the years of the analyzed period. Then, we identified that the estimated value spent on traffic accidents represented 15\% in 2013 and 2014 and $6.8 \%$ for 2015. 
The value of Health was selected, as it was the only one available for the period in question on the city's website, and this sector is closely related to the consequences of accidents. The percentage can be verified in Table 4.

Table 4 - Jataí (GO): relationship between the value received by health and the costs of accidents, 2013 to 2015.

\begin{tabular}{|llll|}
\hline Year & Revenue & Cost with accidents & $\%$ \\
\hline 2013 & $R \$ 35,999,483.94$ & $R \$ 5,556,432.29$ & 15.43 \\
\hline 2014 & $R \$ 43,156,303.35$ & $R \$ 6,695,724.25$ & 15.51 \\
\hline 2015 & $R \$ 52,969,307.77$ & $R \$ 3,602,766.76$ & 6.8 \\
\hline
\end{tabular}

Source: Prefeitura Municipal de Jataí (2018)

Organization: SILVA, Juliana Freitas (2018).

\section{Mapping of traffic accidents involving motorcyclists in Jataí - GO}

With the map it is possible to understand where the accidents occurred in Jataí and, as a result, one can develop strategies and point to resources that can minimize future occurrences. Figure 2 shows the density of accidents with motorcyclists that occurred at the intersections of the city.

In Figure 2, one can note that the highest concentration of accidents occurred in five neighborhoods, namely Setor Aeroporto, Antena, Central, Santa Maria I, Santa Maria II and Samuel Graham, which are the oldest neighborhoods of the city. When analyzing the accidents that occurred in 2013, there were some neighborhoods in which no accidents were reported, such as Setor Industrial, Fabriny, Cohacol5, Setor Sul to the south and Sítios do Recreio Alvorada to the north, Setor Colina and Jacutinga to the east. These neighborhoods have, as a similar characteristic, the presence of residences as well as only local shops, designed to meet some needs of their community.

Thus, most people do not stay in the neighborhoods during the day, because they do not work or study there. Instead, they use their residences largely at night and on weekends, so these places have characteristics of neighborhood-dormitory. Associated with this, Guth (2015) presents the neighborhooddormitories as a result of real estate speculation, which causes people who are unable to buy a house in more central areas to move to more peripheral areas.

According to information obtained in the police reports, of the motorcycle accidents in 2015 , about $10 \%$ occurred at an intersection that had a traffic circle or a rotary as a measure of traffic reduction and orientation. In 2014, almost $6 \%$ (28) occurred in the same situation and, in $2013,8 \%$ of accidents occurred at an intersection with a rotary. 
These data demonstrate that the physical conditions of municipal roads and their local particularities such as traffic signaling and control allow either reduction or increase in the occurrence of traffic accidents, as well as the behavior of drivers who use the system.

Traffic circles facilitate traffic, as they are well-defined areas and can guide vehicles as long as they also have driver priority signs and horizontal signs that help in identifying the locations of drivers and pedestrians. In 2013 alone, among the 419 accidents, 136 occurred with the presence of a STOP sign as traffic control, corresponding to $30 \%$ of the total. In other words, at intersections, the sign indicating the stop alone is not enough to reduce accidents.

In 2014, the number was even higher. Of the total of 486 accidents, 248 had only the STOP sign, resulting in $51 \%$ occurrences. In 2015 , the number corresponded to $48 \%$ of the accidents. Therefore, when comparing traffic control strategies, the traffic circle is a good option. Among the numbers of the three years accumulated, the traffic control situation in which fewer accidents occurred was that with the presence of the Military Police Officer, totaling six (06) occurrences out of a total of 1,118 accidents.

\section{Conclusions}

In Jataí, much still needs to be done about traffic. It can be noted that in the city there is a tendency, as in the entire country, to solve immediate problems without planning for long-term solutions. This behavior hinders improvements in roads, signaling conditions, education of drivers etc., because specific actions do not cover the whole and are just palliative measures that have little impact on the overall situation.

Many peculiarities of the city made it possible to broaden the view of this study. The cost of accidents is very high and represents a public health challenge for the municipality, because the money could be invested in other more urgent issues of the population.

The data contained in this work are expected to provide great support for decision-making and improvement of traffic conditions for all drivers because, when this happens, everyone benefits. It is important to highlight that plans and projects have the ability to trigger actions of the government to improve traffic, as well as research and study data.

We also observed the relevance of the urban planning authority being always linked to all the activities required by it, because the proximity to the real scenario promotes the analysis from the various data collected. Studies that have these important data, related to either the spatialization of geographic information or costs of traffic accidents, are an opportunity to identify critical points, sometimes recognized by sections or roads, that may also show the places that most attract people and vehicles.

These data provide more reliability about the place for intervention, as well as impacts originated from there. Then, it is possible to define actions that can minimize serious problems such as traffic accidents anywhere. It is known that many variables can influence urban traffic, because the possible consequences can be very peculiar or very different from each other, which is another important aspect to 
consider. Therefore, it is proven that this study does not end the discussion on the subject, but rather promotes the discussion from points of view that encourage planning, debate and decision-making in favor of safer traffic.

\section{Research highlights}

- - We use ArcGis 10.1 software to produce the survey maps.

- - This made it possible to assess the points of greatest concentration of accidents.

\section{Abbreviations}

ANTP: National Association of Public Transport;

CPI: Consumer Price Index;

CTB: Brazilian Traffic Code;

DATASUS: Informatics Department of the Unified Health System;

DENATRAN: National Traffic Department;

GIS: Geographic Information Systems;

IBGE: Institute of Geography and Statistics;

IPEA: Social and Economic Impacts of Traffic Accidents in Brazilian Urban Agglomerations;

IPVA: motor vehicle property tax;

MP: Military Police;

ONSV: National Observatory of Road Safety;

RIPSA: the Interagency Health Information Network;

TAR: traffic accident reports;

TUC: Total Unit Cost;

UV: Unit Value;

WHO:World Health Organization.

\section{Declarations}

\section{Acknowledgments}


To the Goiás State Research Support Foundation for granting the scholarship during the master's degree course.

\section{Availability of data and materials}

The datasets used and analysed during study are available from the corresponding author.

\section{Consent for publication}

Not applicable.

\section{Competing interests}

The authors declare that they have no competing interests

\section{Funding information}

Not applicable.

\section{Author details}

1. PhD Student of the Graduate Program in Geography - Federal University of Jataí. Jataí-Goiás-Brazil.

2. Coordinator of the Laboratory of Urban Geography and Health - Federal University of Jataí. Jataí, Goiás - Brazil. Professor at the Graduate Program in Geography - Federal University of Jataí. Jataí, Goiás - Brazil

\section{Authors' contributions}

JFS drafted the manuscript and contributed to the paper conceptualization

and data collection. MJR contributed to the paper conceptualization. The authors reviewed and provided feedback to the manuscript. The authors read and approved the fnal manuscript.

\section{Ethics approval and consent to participate}

For being primary data, the project was submitted to the Research Ethics Committee of the Federal University of Goiás and was approved on May 26, 2017, under protocol $n^{\circ} 2.085 .386$ and CAAE $n^{\circ}$ 62115916.3.0000.5083.

\section{Competing interests}

The authors declare that they have no confict of interest.

\section{References}


BANCO CENTRAL DO BRASIL. Calculadora do Cidadão. Available at: <https://www3.bcb.gov.br/CALCIDADAO/publico/exibirFormCorrecaoValores.do? method=exi birFormCorrecaoValores>. Access on May 20, 2018.

BRASIL. Boletim Epidemiológico 2. O Impacto dos Acidentes de Trânsito para a Previdência Social. 1. ed. Brasília: MPS, 2016,

BRASIL. Lei nº 9.503 de 23 de set. de 1997. Institui o Código de Trânsito Brasileiro. Available at: <http://www.planalto.gov.br/ccivil_03/Leis/19503.htm>. Access on May 10, 2018.

CABRAL, A. P.;SOUZA, W. V.;LIMA, M. L. Serviço de atendimento móvel de urgência: um observatório dos acidentes de transportes terrestre em nível local. RevBrasEpidemiol, 2011.

CALCULADOR. IPCA (Índice Nacional do Preço do Consumidor Amplo). Available at<http://www.calculador.com.br/calculo/correcao-valor-por-indice\#Resultado>. Access on May 21, 2018.

CHAGAS, Denise Martins. Estudos sobre fatores contribuintes de acidentes de trânsito urbano.2011, 114 f. Dissertação (Mestrado em Engenharia de Produção) - Universidade Federal do Rio Grande do Sul UFRGS. Rio Grande do Sul, 2011. Available at:

<http://www.lume.ufrgs.br/bitstream/handle/10183/32553/000786219.pdf?sequence=1>. Access on: Jan. 13, 2017.

DATASUS/RIPSA. Indicadores e Dados Básicos para a Saúde no Brasil (IDB). Available at: http://www.ripsa.org.br/vhl/indicadores-e-dados-basicospara-a-saude-no-brasil-idb/base-de-dados-idb/, 2016. Access on May 29, 2018.

DENATRAN. Manual de Procedimentos do Sistema Nacional de Estatísticas de Acidentes de Trânsito SINET. Ministério da Justiça, Departamento Nacional de Trânsito, Brasília, DF, 2001.

GUIMARÃES, R. B. Saúde: fundamentos de Geografia humana. São Paulo: Editora Unesp Digital, 2015.

GUTH, D. Mobilidade, bicicleta e desigualdade social. São Paulo. 2015. Available at: <http://www.mobilize.org.br/noticias/8387/mobilidade-bicicleta-e-desigualdade-social.html>. Access on April 05, 2018.

IBGE. Estimativas de População. Instituto Brasileiro de Geografia e Estatística. Available at: $<$ https://cidades.ibge.gov.br/brasil/go/jatai/panorama>. Access on October 9, 2020.

IPEA. Impactos Sociais e Econômicos dos Acidentes de Trânsito nas Aglomerações Urbanas Brasileiras. Instituto de Pesquisas Econômicas Aplicadas, Brasília, DF, 2003.

JATAÍ. Lei de Acesso a Informação. Transferência de recursos. Available at: $<$ http://prefeituradejatai.sigepnet.com.br/informacao/transferencia_de_recursos.php $>$. Access on June 5, 2018. 
OMS. Organização Mundial de Saúde. Classificação Estatística Internacional de Doenças e Problemas relacionados à Saúde. 10. rev. Genebra: Organização Mundial da Saúde, 2008. Available at: http://www.datasus.gov.br/cid10/V2008/cid10.htm. Access on May 29, 2018.

ONSV. Custos Per Capita dos Acidentes de Trânsito no Brasil. Observatório Nacional de Segurança Viária, Brasília, DF, 2016. Available at: <https://www.onsv.org.br/observatorio-divulga-custos-per-capita-dosacidentes-de-transito-no-pais/> Access on: May 28, 2018.

PREFEITURA MUNICIPAL DE JATAII. Mapa da cidade de Jataí, (2017). Available at: < http://www.jatai.go.gov.br/download/mapa-urbano-de-jatai-pdf/> Access on: Apr 09, 2017.

QUEIROZ, M. P. Análise espacial dos acidentes de trânsito do município de Fortaleza. 2003. 124 f. Dissertação (Mestrado em Engenharia de Transportes) - Universidade Federal do Ceará, Fortaleza, 2003.

ROSA, R. Geotecnologias na Geografia aplicada. Revista do Departamento de Geografia, São Paulo, v. 16, p. 81-90, abr. 2005.

SANTOS, S. M.; BARCELLOS, C. (orgs). Abordagens espaciais na saúde pública. Brasília: Ministério da Saúde, 2006.

SILVA, R. M. Acidentes de trânsito com envolvimento de motociclistas: Uberlândia - 2002 a 2004. 2007. 153 f. Dissertação (Mestrado em Geografia) - Universidade Federal de Uberlândia, Uberlândia, 2007.

SIMÕES. F. A SEGTRANS: Sistema de Gestão da Segurança no Trânsito Urbano. Tese de Doutorado, 220p. Programa de Pós Graduação em Transportes. Escola de Engenharia de São Carlos, universidade de São Paulo, São Carlos, 2001.

SOUZA, M. L. Os conceitos fundamentais da pesquisa sócio-espacial. 1.ed. Rio de Janeiro: Bertrand Brasil, 2013.

SOUZA, R. K.; COSTA, F., R. Geotecnologias aplicadas à análise espaço temporal da expansão urbana nos municípios da microrregião de Pau dos Ferros-RN. Available at: <https://www.ufpe.br/cgtg/SIMGEOIV/CD/artigos/SReFOTO/055_4.pdf>. Access on: Aug. 24, 2016. SOUZA, F. K. B.; SALAZA, M. M. Z.; SPOHR, N.; SANTOS, E. S. Análise dos custos e mapeamento dos acidentes de trânsito em Cuiabá-MT de2014 a 2015. Anais do VIII GeoSaúde. Dourados, Brasil, 27 de junho a 01 de julho de 2017. Available at: <http://www.geosaude.org/anais>. Access on June 05, 2018.

WAISELFISZ, J. J. Mapa da Violência 2013: Acidentes de Trânsito e Motocicletas. Centro Brasileiro de Estudos Latino-Americanos. FLACSO Brasil, 2013.

World Health Organization, WHO. Injuries and Violence: The Facts. Geneva: World Health Organization; 2014. Available at: <http://apps.who.int/iris/bitstream/10665/44288/1/ 9789241599375_eng.pdf>. Access on: May 29, 2018 
World Health Organization, WHO. Global status report on road safety. Geneva: World Health Organization, 2015. Available at: <http://www.who.int/violence_injury_prevention/road_safety_status/2015/en/>. Access on: May 29, 2018

\section{Figures}

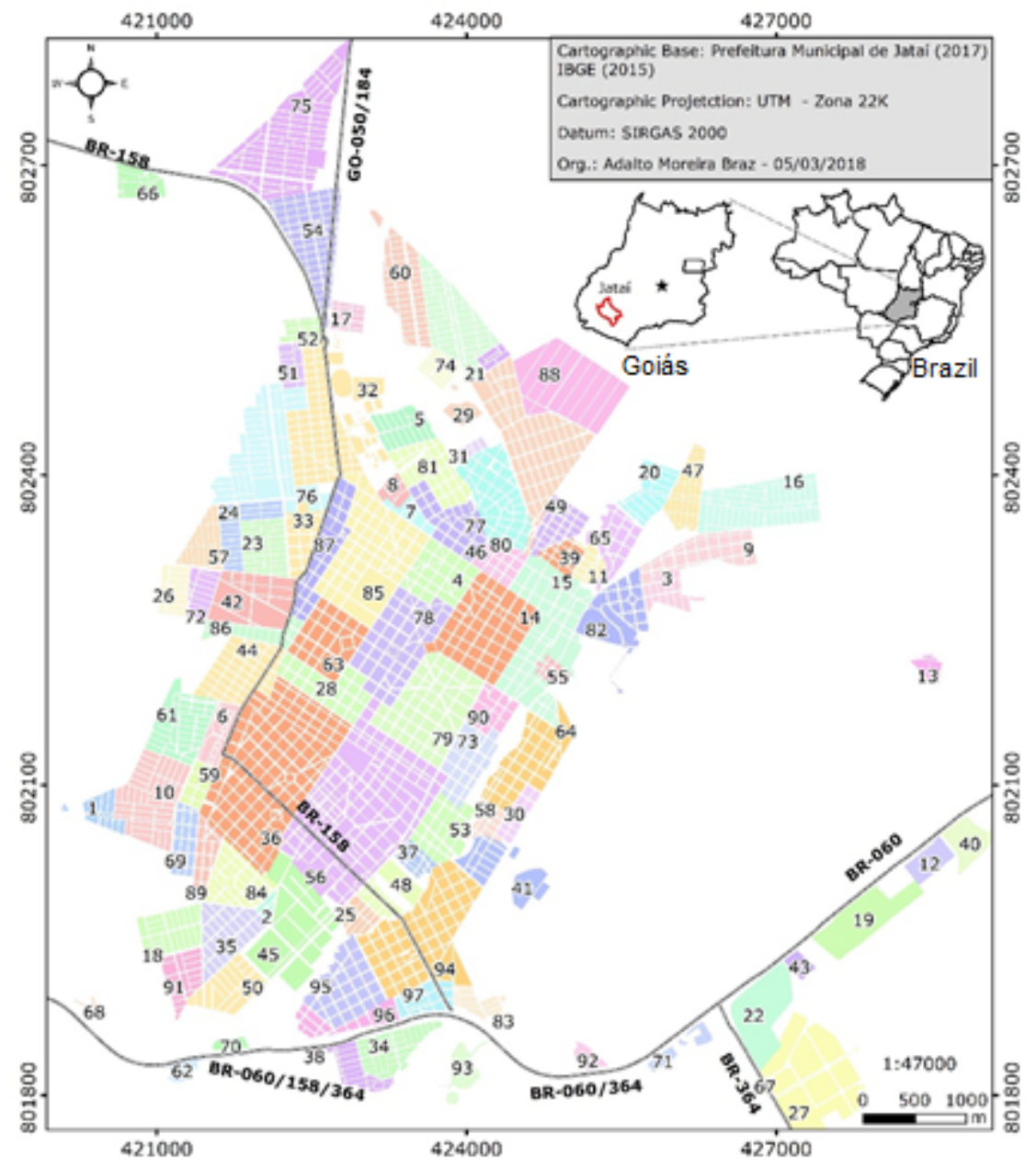

Figure 1

Jataí (G0): location and urban perimeter of the study area, 2017. Source: Prefeitura Municipal de Jataí (2017). 


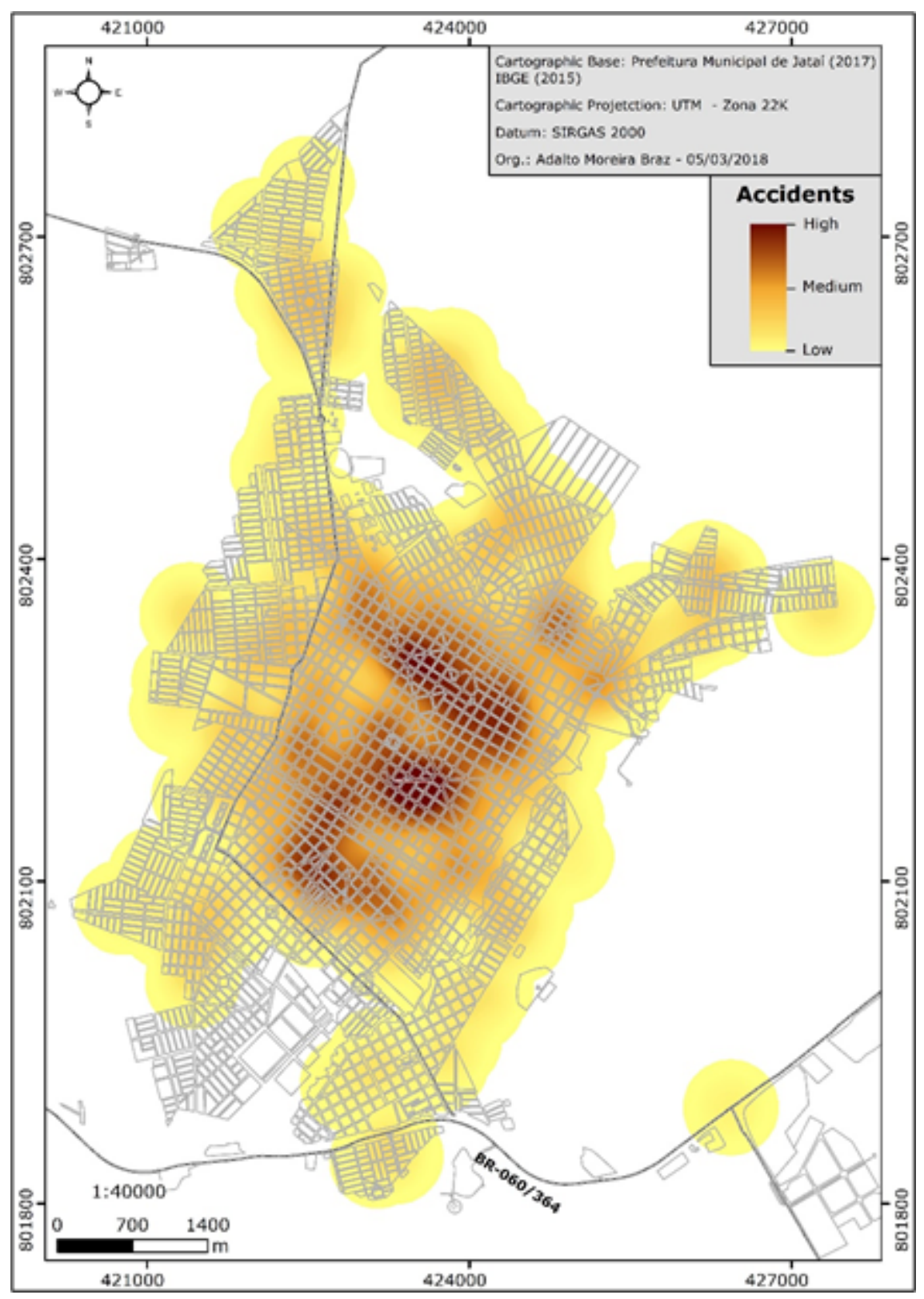

Figure 2

Jataí (GO): density of accidents involving motorcyclists at intersections, 2013 to 2015. Source: TAR of MP (2017). Organization: SILVA, Juliana Freitas (2018). 